\title{
Histopathological diagnosis of acute and chronic rejection in pediatric kidney transplantation
}

\author{
Verena Bröcker • Michael Mengel
}

Received: 13 May 2013 /Revised: 5 September 2013 / Accepted: 13 September 2013 /Published online: 19 October 2013

(C) IPNA 2013

\begin{abstract}
ABO-compatible as well as ABO-incompatible kidney transplantation are well established in the pediatric population. There are particularities in the histopathological evaluation of pediatric kidney transplant biopsies as for example the recurrence of certain diseases different from the adult population. Furthermore, the challenging transition of pediatric renal transplant recipients to adulthood is associated with an increased rate of non-adherence triggered rejection episodes. With modern immunosuppressive drugs, T-cellmediated rejection of renal allografts is well controlled. In contrast, antibody-mediated rejection (AMR) is increasingly recognized as one of the major reasons for allograft loss. However, the 2001 diagnostic Banff criteria for antibodymediated rejection require further refinement, as the morphological spectrum of AMR expands while effective therapeutic strategies are lacking. For example, endarteritis, which traditionally has been attributed to T-cell-mediated rejection, has recently been shown to be part of the AMR spectrum in some cases. Many findings in transplant renal biopsies are not specific for a certain disease but need consideration of differential diagnoses. To use the term "chronic allograft nephropathy" as a diagnostic entity is no longer appropriate. Therefore, the precise identification of specific diseases is paramount in the assessment of transplant renal biopsies in order to enable tailored therapeutic management.
\end{abstract}

Keywords Kidney transplantation · Acute rejection $\cdot$ Chronic rejection · Donor-specific antibodies · Endarteritis · Allograft loss $\cdot$ Banff classification

\footnotetext{
V. Bröcker

Department of Histopathology, Addenbrooke's Hospital, Cambridge University Hospitals NHS Foundation Trust, Cambridge, UK

M. Mengel ( $\square)$

Department of Laboratory Medicine and Pathology, University of Alberta, Edmonton, AB, Canada

e-mail: mmengel@ualberta.ca
}

\section{Introduction}

Since 1995, the 5-year kidney graft survival has not substantially increased and currently, estimated graft survival probabilities are reported to be approx. 84 and $78 \%$ for the first transplant from a living or deceased donor, respectively [1]. These figures decrease in subsequent transplantations. The American data are comparable to European results and similar to the adult population younger than 65 years of age [2].

The most common cause of transplant failure in the pediatric population is reported to be chronic rejection with $35 \%$ [1]. It has been shown recently that a high proportion of transplant losses in adults is attributable to antibody-mediated rejection (AMR) rather than T-cell-mediated cellular rejection and that non-adherence is a major risk factor for late AMR and graft loss [3]. Adolescents are especially susceptible to non-adherence with medication taking. A meta-analysis has shown that the mean prevalence of medication non-adherence is $32 \%$ in pediatric renal transplant recipients but is presumably even higher in the adolescent subgroup [4].

Aplastic, -hypo and dysplastic kidneys together with obstructive uropathy account for approx. $30 \%$ of the primary diagnoses leading to renal transplantation in the pediatric population [1]. Focal segmental glomerular sclerosis (FSGS) is the most common glomerular disease accounting for approx. $11 \%$ of renal transplants [1]. Recurrent primary disease is the reason for graft failure in $6.9 \%$ of cases, but increases in subsequent grafts [1]. However, the risk of recurrence and graft loss varies substantially between the individual diseases. Among the more common diseases with high recurrence rates and high risk of graft loss due to recurrence are primary FSGS, Membrano proliferative glomerulo nephritis (MPGN) type II (Dense deposit disease) and atypical Hemolytic uremic syndrome (HUS) (albeit variable depending on to the underlying genetic defect) [5]. The histological diagnosis of recurrent diseases in renal transplants is rendered by identical approaches as in native kidneys. As this is not in the focus of this article, we refer to respective comprehensive textbooks in this regard. 
Historically, acute rejection was seen more frequently in children compared with adults. This was attributed to an increased immunologic responsiveness in young children $[6,7]$. Altogether, the rejection rates in children have markedly decreased (as seen in adults) during the last decades from $70 \%$ before 1990 to $13 \%$ in the most recent observation period [1]. Current 1-year incidence of acute rejection is only slightly higher in children compared with adults (12.5\% versus $11 \%$ ) [8].

The average expected remaining lifetime of an individual between 0 and 19 years on dialysis is similar to a 45 -year-old in the general population. However, the estimated gain in lifetime following renal transplantation is another 25 years [2]. This underscores the importance of improving the longterm graft survival in the pediatric population with such an enormous potential benefit from a functioning graft.

\section{Protocol biopsies in pediatric renal transplant patients}

A protocol biopsy is defined as a renal biopsy sample from a stable graft at a pre-determined point of time after transplantation. The idea is to detect early potentially treatable diseases in the transplant before they cause graft impairment and come to clinical attention. Experiences from over a decade of protocol biopsies in the adult population have created doubts on their utility as a general diagnostic tool in an unselected approach, although the procedure itself has been shown to be relatively safe [9]. Their implementation in specialized centers, however, has created substantial insight into the natural course of allograft pathology [10-12]. Results from a small recent study in pediatric patients suggest potential benefit from protocol biopsy-driven intervention, which has not been unequivocally shown in adults [13]. In general, it has been proposed to confine the use of protocol biopsies to immunologically high-risk patients $[11,14]$. Consensus recommendations on the use of protocol biopsies in the context of presence or absence of donor-specific antibodies have recently been published [15].

\section{Cell-mediated rejection}

Cell-mediated rejection (CMR) is conducted by effector T cells originating from the lymphoid organs and infiltrating the allograft, leading to an inflammatory response. Thus, the term "cell-mediated rejection" refers to T-cell-mediated rejection (TCMR). The T cells are thought to be reactive against donor alloantigen [16]. The interstitium is permeated by this cellular infiltrate, eventually leading to tubulitis lesions (i.e., the infiltration of T cells between tubular epithelial cells, Fig. 1a). Most of the cells in the interstitium are CD4+ and CD8+ T cells and CD68+ monocyte/macrophages. Eosinophils may also be present, possibly indicative of a worse outcome [17]. Although tubulitis is frequently considered as fairly specific for TCMR, recent data suggest that tubulitis is the consequence rather than the cause of epithelial injury [18]. Furthermore, tubulitis can be observed in other diseases of renal allograft, e.g., polyoma virus-associated nephritis, and also in native kidneys, e.g., interstitial nephritis.

Acute cell-mediated rejection

Acute tubulo-interstitial rejection consists of interstitial edema with a mononuclear infiltrate accompanied by tubulitis lesions. For a diagnosis of acute CMR under Banff criteria (Table 1), interstitial infiltrate ("i $\mathrm{i}$ "-score) and tubulitis (" $\mathrm{t}$ "-score) are graded. Acute CMR, type IA, requires tubulitis reaching a threshold of "moderate" severity accompanied by a "significant" inflammatory infiltrate. If there is more intense tubulitis, a designation of acute CMR, type IB, can be made, which has been shown to be associated with a worse prognosis [19]. Such more severe tubulo-interstitial acute CMR is primarily characterized by multifocal rupture/destruction of tubular basement membranes, putatively indicating irreversible destruction of nephrons.

In the category of tubulointerstitial rejection, a "gray zone" exists in which either only tubulitis is present without a substantial interstitial infiltrate or an interstitial infiltrate is accompanied by only mild tubulitis. Such cases are termed "borderline"/"suspicious for acute CMR" [20]. However, the implications of such lesions are controversial, and it depends on the center and the type of biopsy (indication versus protocol biopsy) whether these "borderline" cases are regarded and treated as rejection or not. A recent study using gene expression analysis in borderline cases revealed that $1 / 3$ of these cases presents with a molecular phenotype identical to 'true' TCMR cases, while $2 / 3$ were similar to cases showing no evidence of rejection [21]. Previous studies indicate that withholding additional rejection therapy may be appropriate in some of these cases [22]. Additional clinical and histopathological features such as concomitant impairment of renal function and presence of interstitial edema and tubular injury, which are an integral part of a rejection diagnosis in the CCTT-classification of renal allograft rejection, may be helpful in guiding clinical decisions for further treatment in "borderline" cases [23]. However, no prospective clinical trials have ever been conducted to assess whether borderline rejection requires similar treatment as overt TCMR. It is hoped that further research will clarify the significance of the "borderline" category and eliminate this ambiguous "gray zone" [21].

Although tubulitis in the context of acute cellular rejection is caused by T-cells, B-cells are frequently found in renal allografts and their role is still a matter of debate.

B cells may play multiple roles in the immune responses to allografts: in production of high-affinity donor-specific antibody in the central lymphoid organs; as antigen-presenting cells (APCs) in secondary lymphoid organs; and in local inflammatory processes in the graft through interactions with $\mathrm{T}$ cells, 

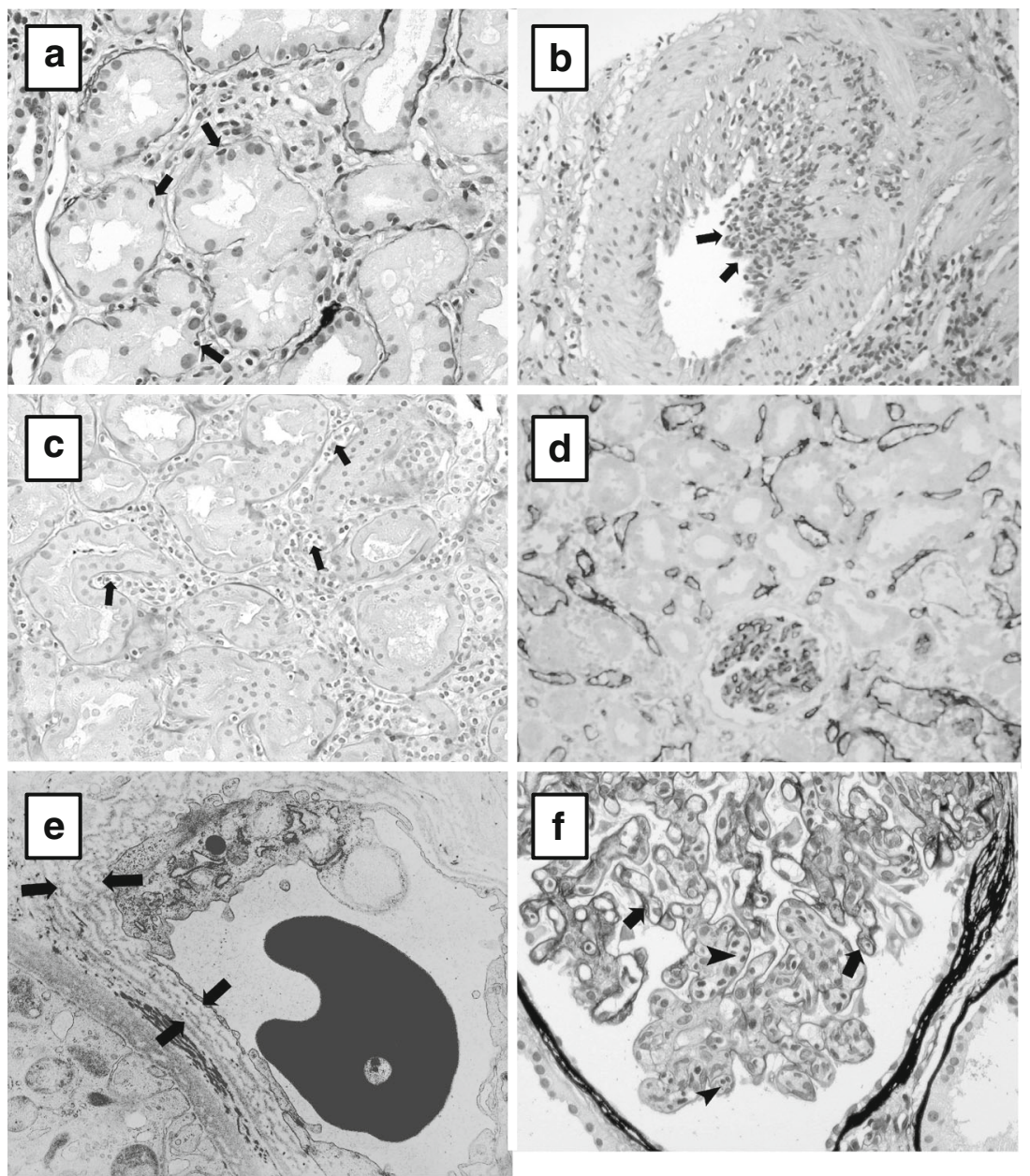

Fig. 1 a Tubulitis: Lymphocytes (arrows) infiltrate the tubules (Banff " $t$ "lesion), which is suspicious of acute cellular rejection. b Endothelialitis: Inflammatory cells are seen below the arterial endothelium (arrows, Banff "v"-lesion), which can be associated with donor-specific anti-HLA antibodies. c Peritubular capillaritis: Accumulation of inflammatory cells in peritubular capillaries (arrows) of a renal allograft (Banff "ptc"-lesion) as one of the morphological features of microcirculation injury in antibodymediated rejection. d C4d positivity: Diffuse, linear, and circumferential $\mathrm{C} 4 \mathrm{~d}$ deposition in peritubular capillaries as a biomarker for complement

dendritic cells, and macrophages. Recent reports have focused on the significance of $\mathrm{CD} 20^{+} \mathrm{B}$ cells infiltrates in kidney allografts, suggesting that these infiltrates are associated with poor graft survival [24-27]. However, this association is complex and still controversial [28-32]. Gene expression studies revealed that $\mathrm{B}$ cells are features of late biopsies and associated with inflammation in areas of fibrosis, and the mere fact of having a late biopsy itself is associated with a poor prognosis. While the significance of B cell infiltrates remains unclear, it is relevant because of potential consequences for therapy, since highly effective anti-B cell drugs are available [33].

The presence of $\mathrm{CD} 20+\mathrm{B}$ cells in renal allografts is often associated with the aggregation of infiltrates into lymphoid clusters (LC), although some B cells can also be found in diffuse interstitial infiltrates $[34,35]$. Lymphoid clusters in activation in the microcirculation of the allograft. e Peritubular capillary basement membrane multilayering: Electron microscopy picture showing multilayering (between arrows) of the basement membrane of a peritubular capillary, indicating chronic antibody-mediated rejection. f Glomerulitis and initial transplant glomerulopathy: Mononuclear inflammatory cells are present within glomerular capillaries (arrowheads, Banff "g"-lesion). In addition, segmental double contours are seen in some glomerular loops (arrows, Banff "cg"-lesion). This is suspicious of chronic-active antibodymediated rejection

renal allografts represent a mixed aggregate of $\mathrm{CD} 20^{+}$cells with $\mathrm{T}$ cells and macrophages in the immediate vicinity and can comprise between 5 and $90 \% \mathrm{CD} 20^{+}$cells [31]. The prevalence of LC varies considerably between studies (between 15 and $59 \%$ in indication biopsies, $30 \%$ in protocol biopsies [34]. The variability of these results is influenced by the lack of uniform criteria for the definition of lymphoid clusters. Although B-cell nodular infiltrates resemble ectopic germinal centers in grafts that were explanted because of terminal rejection inducing graft failure [36], it is not clear if the nodular infiltrates observed in transplant biopsies share similar features with these end-stage organs. The key question that yet needs to be answered is whether the dense B cell nodular infiltrates observed in some renal allografts are functioning in generation of effector $\mathrm{T}$ cells or of high-affinity 
Table 1 Banff classification for renal allograft pathology: diagnostic categories summarized with updates (adapted from [20], used with permission)

\section{Cat. Features}

1 Normal

2 Ab-mediated changes ( \pm Cat. 3, 4, 5, 6)

Circulating antidonor $\mathrm{Ab}, \mathrm{C} 4 \mathrm{~d}+$, and allograft pathology

- $\mathrm{C} 4 \mathrm{~d}$ deposition without morphologic evidence of active rejection $\mathrm{C} 4 \mathrm{~d}+$, circulating antidonor $\mathrm{Ab}$, no signs of acute or chronic TCMR or AMR (i.e., g0, cg0, ptc0, no ptc lamination $[<5$ layers by EM], no ATN-like minimal inflammation) [Considered indeterminate if simultaneous borderline changes]

- Acute antibody-mediated rejection

$\mathrm{C} 4 \mathrm{~d}+$, circulating antidonor $\mathrm{Ab}$, morphologic evidence of acute tissue injury

I. ATN-like minimal inflammation

II. Capillary and/or glomerular inflammation ( $\mathrm{ptc} / \mathrm{g}>0)$ and/or thrombosis

III. Arterial—v3

- Chronic active antibody-mediated rejection

$\mathrm{C} 4 \mathrm{~d}+$, circulating antidonor $\mathrm{Ab}$, morphologic evidence of chronic tissue injury [glomerular double contours and/or ptc lamination and/or interstitial fibrosis/tubular atrophy and/or fibrous intimal thickening in arteries]

3 Borderline changes: 'Suspicious' for acute T-cell-mediated rejection $[ \pm$ Cat. $2,5,6]$

No arteritis but present are tubulitis ( $\mathrm{t} 1, \mathrm{t} 2$, or $\mathrm{t} 3$ ) with minor interstitial infiltration (i0 or i1) or interstitial infiltration (i2, i3) with mild tubulitis (t1)

4 T-cell-mediated rejection (TCMR) $[ \pm$ Cat. 2, 5, 6]

- Acute TCMR

IA. Significant interstitial infiltration

( $>25 \%$ of parenchyma affected, i2 or i3) and foci of moderate tubulitis ( $\mathrm{t} 2$ )

IB. Significant interstitial infiltration

( $>25 \%$ of parenchyma affected, i2 or i3) and foci of severe tubulitis (t3)

IIA. Mild to moderate intimal arteritis (v1)

IIB. Severe intimal arteritis comprising $>25 \%$ of the luminal area (v2)

III. 'Transmural' arteritis and/or arterial fibrinoid change and necrosis of medial smooth muscle with accompanying lymphocytic inflammation

- Chronic active T-cell-mediated rejection

'Chronic allograft arteriopathy' (arterial intimal fibrosis with mononuclear infiltration of fibrosis, formation of neo-intima)

5 Interstitial fibrosis and tubular atrophy (IFTA), no evidence of specific etiology

[Graded according to IFTA; may also have nonspecific vascular and glomerular sclerosis]

I. Mild IFTA ( $<25 \%$ of cortical area)

II. Moderate IFTA (25-50\% of cortical area)

III. Severe IFTA/loss ( $>25 \%$ of cortical area)

6 Other

Changes not due to rejection - acute or chronic - ay include cg or cv lesions, \pm Cat. 2, 3, 4, 5 antibody, via their acquired structural and functional properties of tertiary lymphoid organs. Recent evidence emerged that $\mathrm{B}$ cells can in addition to present antigen and enhance $\mathrm{T}$ cell activation also regulated and inhibit immune responses. A subset of B cells, co-called "regulatory B cells" (Bregs) act independently from antibody production and antigen presentation, and are generally IL-10 dependent [37]. Key future directions in this regard include finding more specific markers for Bregs and through this find ways to inhibit antibodyproducing B cells without depleting Bregs.

The presence of subendothelial inflammatory cells in the arteries is referred to as "endothelialitis", "vascular rejection", or more accurately "endarteritis" (Fig. 1b). Mild to moderate endarteritis is diagnosed as acute CMR, type IIA according to Banff criteria. If severe endarteritis is present, a designation of type IIB acute CMR can be rendered [20]. These cases have been shown to be associated with a worse prognosis compared to Banff type IIA cases [38]. Cases with transmural arteritis and/or arterial fibrinoid changes are diagnosed as acute CMR, type III. However, it is recognized that such lesions may often have an antibody-mediated component [20]. Studies have indicated a worse prognosis of cases with endarteritis, but it needs to be taken into consideration that most of these studies were done prior to sensitive antibody testing and thus may represent AMR instead of CMR [39].

Results from a retrospective multicenter case cohort study presented at the 2011 Banff meeting indicated that cases with so-called "isolated v-lesions" (i.e., endarteritis in the absence of significant tubulointerstitial inflammation or capillaritis) might represent a heterogeneous group of disease processes [11]. After the exclusion of AMR cases, two types of isolated v-lesion cases were identified: Those associated with TCMR and those with delayed graft function. More recently, Lefaucheur et al. found that one-third of all vascular rejections were antibody mediated, half of which showed $\mathrm{v} 1$ lesions only [40]. Thus, this distinct group of antibody-mediated vascular rejection is not yet represented in the current Banff classification. Furthermore, the same group from Paris recently reported that donor-specific antibodies (DSAs) very likely contribute to the severity and progression of arteriosclerosis in renal transplants [41]. Comparing protocol biopsies from patients with and without DSA showed that arteriosclerosis significantly progressed between month 3 and month 12 after transplant in DSA-positive patients while among DSA-negative patients no statistically significant progression was observed during the same timeframe. Available biopsies at later time points in some of the patients supported a rate of progression of arteriosclerosis in DSA-negative patients that was approximately one-third of that observed in DSA-positive patients. Accelerated arteriosclerosis was also significantly associated with peritubular capillaritis and glomerulitis, i.e., features of AMR. These observations strongly support the hypothesis that DSA accelerate post-transplant progression of 
arteriosclerosis. Therefore, a more differentiated diagnostic and therapeutic approach towards cases with endarteritis and transplant vasculopathy seems warranted.

\section{Chronic cell-mediated rejection}

Interstitial fibrosis and tubular atrophy (IFTA) is the non-specific final common pathway in both chronic CMR and AMR as well as in other forms of graft deterioration, e.g., PVAN and recurrent disease [42]. However, the only accepted diagnostic feature for chronic CMR under Banff criteria is the presence of intimal inflammation in the setting of chronic allograft arteriopathy consisting of arterial intimal fibrosis with mononuclear infiltration and formation of a neo-intima [20]. However, as discussed above, recent data suggest that DSA play a major role in accelerated arteriosclerosis in renal allografts [41].

With progressing IFTA, the renal tubules shrink, acquire wrinkled, thickened tubular basement membranes, and are infiltrated by inflammatory cells. Currently, inflammation in areas of IFTA is not considered for the Banff i score for the diagnosis of CMR. However, recent studies have shown the importance of inflammation in areas of fibrosis, suggesting a role in chronic rejection and ultimate graft deterioration, at least as a robust prognostic marker [43-45]. A scoring system has been proposed to address "total interstitial inflammation" and is currently under review for its inter-observer reproducibility and clinical utility by the Banff Working Group [46, 47].

\section{Antibody-mediated rejection}

Antibody-mediated rejection (AMR) has emerged as a major clinical challenge and has recently been identified as the most frequent cause for renal allograft failure in adults [48, 49]. Donor-specific anti HLA-antibodies (DSA) are identified in the vast majority of AMR and patients with DSA are at increased risk for allograft failure. The primary target of DSA is the endothelium of the microcirculation in the allograft. Clinical management of AMR differs significantly from TCMR. Therefore, accurate diagnosis of AMR is crucial. However, the morphological spectrum of AMR is heterogeneous and comprises a set of non-specific morphological lesions which are nevertheless an essential part of current diagnostic criteria for AMR along with $\mathrm{C} 4 \mathrm{~d}$ deposition on the endothelium, presence of DSA, and graft dysfunction [24]. Chronic AMR has been widely recognized in kidney transplants, but needs yet to be defined in other organ transplants. Despite being a significant contributor to late graft loss, it is often missed due to limitations of current diagnostic criteria. In particular the lack of sensitivity of $\mathrm{C} 4 \mathrm{~d}$ and the limited specificity of DSA account for most missed AMR cases.
Acute antibody-mediated rejection

With the exception of hyper-acute AMR mediated by preexisting unrecognized DSA [50, 51], T cells were thought to be the major determinant in graft rejection. However, over the past decade, it has become clear that significant graft injury occurs through AMR-mediated primarily by donor-specific anti-HLA antibodies [52]. Consequently, in 2001 AMR was introduced as a diagnostic category into the Banff classification [24]. AMR contributes to both early and in particular late graft loss $[48,49]$. Antibodies can cause tissue injury through three main pathways: the classical activation of complement, via direct activation of the antigen-expressing target endothelial cell, and through cell-mediated cytotoxicity after binding to Fc receptors of neutrophils, macrophages, and NK cells [52-54]. Since donor HLA is widely expressed in the microcirculation of the allograft, these pathways can all culminate in endothelial injury.

Morphologically, acute AMR presents with three main patterns of injury, which are reflected in the Banff classification [46]. Type/Grade I: An acute tubular necrosis (ATN)-like minimal inflammation pattern; Type/Grade II: A pattern including peritubular capillary (PTC) and/or glomerular capillary inflammation (=microcirculation inflammation: Fig. 1c and f), sometimes accompanied by microthrombi. Type/Grade III: Presence of vascular fibrinoid necrosis. According to current Banff consensus criteria, two or more criteria are required for the diagnosis of AMR in addition to one of the injury patterns described above: evidence of DSA and the deposition of the complement split product component $\mathrm{C} 4 \mathrm{~d}$ on the endothelium of PTCs (Fig. 1d) [20]. Ultrastructurally, peritubular and glomerular capillary endothelium show signs of injury with cell enlargement, loss of fenestration, detachment from basement membranes with lamina rara interna widening, lysis, and apoptosis [55].

\section{Chronic antibody-mediated rejection}

Chronic antibody-mediated rejection (CAMR) is characterized by structural remodeling of the allograft microvasculature but also larger arteries (intimal hyperplasia) with secondary IFTA and eventual decline in renal allograft function. As a consequence of chronic antibody-mediated injury to the microcirculation, structural remodeling of glomerular basement membranes takes place with lamellation and duplication, resulting in so-called transplant glomerulopathy with double contours appreciable by light microscopy (Fig. 1f). Similar changes take place in peritubular capillaries (PTC), leading to basement membrane multilayering (Fig. 1e) [40]. According to Banff criteria, prerequisites for a diagnosis of CAMR are the evidence of chronic tissue injury, the presence of $\mathrm{C} 4 \mathrm{~d}$ and a documented DSA [20]. Chronic tissue injury includes glomerular double contours, PTC basement membrane multilayering, IFTA, and fibrous thickening in arteries [20]. 
At least two of four of these criteria are typically required for a diagnosis of CAMR. Glomerular and PTC basement membrane multilayering are considered the most valuable evidence of chronic antibody-mediated injury [56]. Similar to acute AMR, at least some degree of glomerulitis and/or peritubular capillaritis is typically present in most biopsies with CAMR. This can be interpreted as ongoing disease activity and thus risk for progression. The glomerular inflammatory infiltrate is mostly composed of CD68+ monocytes with fewer numbers of $\mathrm{CD} 3+\mathrm{T}$ cells and occasional neutrophils. PTCs may be positive for $\mathrm{C} 4 \mathrm{~d}$ in $\mathrm{CAMR}$, and $\mathrm{C} 4 \mathrm{~d}$ staining can also be seen in glomeruli with double contours. C4d and DSA may be intermittently present throughout this process. AMR may proceed to allograft failure within months or may be procrastinated over years, depending on the compliance and immunosuppressive status of the patient [3].

Attention has recently been drawn to so-called "C4d-negative AMR". These cases have DSA and morphological evidence of microcirculation injury but lack C4d positivity in PTC endothelium. Negativity for $\mathrm{C} 4 \mathrm{~d}$ in AMR can be explained by various mechanisms: complement independent antibodymediated injury, lack of sensitivity and reproducibility of the staining methods, arbitrary criteria for defining positivity, and time-dependent degradation of $\mathrm{C} 4 \mathrm{~d}$-deposits in the microcirculation. Inter-institutional reproducibility of $\mathrm{C} 4 \mathrm{~d}$ staining has recently been shown to be poor [57]. Molecular studies identified a subset of cases with DSA and morphological features of antibody-mediated injury showing increased expression of endothelial cell-associated transcripts as a sign of endothelial cell activation and stress [58]. These data suggest that 50-60\% of AMR cases are missed by current Banff criteria due to C4dnegativity. Eventually, this will be added to the Banff diagnostic armamentarium as a distinct category of AMR. However, data is still being reviewed by a respective Banff Working Group regarding the significance of this entity in attempt to provide valid diagnostic criteria, a task on the agenda for the 2013 Banff meeting $[11,59]$.

\section{Particularities in ABO-incompatible transplantation}

A peculiar scenario occurs in ABO-incompatible transplantation, related to the presence of PTC C4d deposition in the absence of other evidence of antibody-mediated injury, a phenomenon called "accommodation". Anti-blood group antibodies may be detectable in these cases. Signs of acute or chronic TCMR or AMR are absent. More specifically, there is no ATN-like minimal inflammation, no glomerulitis, no transplant glomerulopathy, no peritubular capillaritis, and no PTC basement membrane multilayering. These cases are considered to represent " $\mathrm{C} 4 \mathrm{~d}$ deposition without evidence of active rejection" under current Banff criteria [20]. Accommodation is often described in the setting of ABO-incompatible transplantation, where non-HLA anti-blood group antibodies are present. The long-term significance of this observation is still under investigation $[60,61]$. In contrast, those cases in which anti-HLA DSA occur de novo have been described to develop typical AMR and thus are associated with an inferior prognosis [62].

\section{Differential diagnoses}

Many of the findings in transplant kidney biopsies are neither specific nor unique to the transplant setting, but may be seen in various diseases in transplant as well as native kidney biopsies (Table 2). Interstitial inflammation and tubulitis, for example, are not specific for acute allograft rejection, but may indicate bacterial or viral infection, allergic drug reaction, or PTLD. Often, a correct diagnosis can not be made without careful clinico-pathological correlation. Some of the findings that are typically problematic in terms of possible differential diagnoses are discussed in the following sections.

Differential diagnosis: polyoma virus-associated nephritis (PVAN)

The regimen of immunosuppression is one of the main risk factors for the development of polyoma virus nephropathy in kidney allografts [63]. The prevalence of PVAN varies between 1 and $10 \%$ in the literature and the risk of graft failure from established PVAN is high [64]. However, it is likely that the prevalence of PVAN and subsequent graft failure will decline due to sufficient PCR screening of blood and urine and early reduction of immunosuppression [65]. PVAN infects the renal tubular epithelium and results in a tubulointerstitial nephritis with often typical cytopathic nuclear changes with nuclear inclusions. The inflammatory infiltrate is frequently rich in plasma cells. The prognosis of late-stage cases with advanced IFTA is poor [64, 66, 67]. It has been postulated that acute CMR and polyoma virus may coexist. However, as long as there is no endarteritis, the differential diagnosis between these two entities is notoriously difficult [68]. Immunohistochemistry directed against the polyoma virus SV40 large $\mathrm{T}$ antigen or in situ hybridization is crucial to detect virally infected cells to confirm the diagnosis.

A histopathological grading system for PVAN has been proposed, but its prognostic significance is debatable [11, 69].

\section{Differential diagnosis: calcineurin inhibitor toxicity}

Calcineurin inhibitors (e.g., ciclosporin and tacrolimus) are highly effective in preventing rejection in renal allografts [16]. However, calcineurin inhibitors can cause both acute and chronic nephrotoxicity [70]. Acute toxicity is characterized by tubular injury with isometric cytoplasmic vacuolization. 
Table 2 Histopathological findings in transplant kidney biopsies and their potential differential diagnoses
${ }^{a}$ PVAN Polyoma virus-associated nephropathy

${ }^{\mathrm{b}}$ Special stains: In situ hybridization/immunohistochemistry/immunofluorescence

${ }^{\mathrm{c}}$ PTLD Post-transplant lymphoproliferative disease

${ }^{\mathrm{d}} \mathrm{CNI}$ Calcineurin inhibitor

${ }^{\mathrm{e}} A M R$ Antibody-mediated rejection

${ }^{\mathrm{f}} D S A$ Donor-specific antibodies

${ }^{\mathrm{g}}$ TMA Thrombotic

microangiopathy

${ }^{\mathrm{h}}$ CIT Cold ischemia time

\begin{tabular}{|c|c|c|}
\hline Histopathological finding & Differential diagnosis & Helpful tool \\
\hline \multirow[t]{6}{*}{ Interstitial inflammation } & Acute/chronic rejection & History of rejections? \\
\hline & Pyelonephritis & Urine culture \\
\hline & Drug reaction & Drug history \\
\hline & PVAN $^{\mathrm{a}}$ & Special stains ${ }^{\mathrm{b}}$ \\
\hline & & Blood virus PCR \\
\hline & PTLD $^{\mathrm{c}}$ & Immunohistochemistry \\
\hline \multirow[t]{5}{*}{ Tubulitis } & Acute/chronic rejection & History of rejections? \\
\hline & Pyelonephritis & Urine culture \\
\hline & Drug reaction & Drug history \\
\hline & PVAN $^{\mathrm{a}}$ & Special stains ${ }^{\mathrm{b}}$ \\
\hline & & Blood virus PCR \\
\hline \multirow[t]{4}{*}{ Arteriolar hyalinosis } & $\mathrm{CNI}^{\mathrm{d}}$ toxicity & $\mathrm{CNI}^{\mathrm{d}}$ levels/duration \\
\hline & Diabetes & Medical history \\
\hline & Hypertension & \\
\hline & Donor related & Zero time/pre-implantation biopsy \\
\hline \multirow[t]{5}{*}{ Glomerular double contours } & Transplant glomerulopathy & Presence of DSA ${ }^{f}$ \\
\hline & in chronic $\mathrm{AMR}^{\mathrm{e}}$ & Previous biopsies with $\mathrm{AMR}^{\mathrm{e}}$ ? \\
\hline & Recurrent/de novo & Special stains \\
\hline & mesangiocapillary GN & Electron microscopy \\
\hline & Chronic TMA ${ }^{\mathrm{g}}$ & Medical history \\
\hline \multirow[t]{6}{*}{ Focal segmental glomerulosclerosis } & Recurrent disease & Medical history \\
\hline & De novo glomerular disease & Special stains \\
\hline & & Electron microscopy \\
\hline & $\mathrm{CNI}^{\mathrm{d}}$ toxicity & \\
\hline & Unknown/non-specific & \\
\hline & Donor related & Zero time/pre-implantation biopsy \\
\hline \multirow[t]{4}{*}{ Acute tubular injury } & $\mathrm{CNI}^{\mathrm{d}}$ toxicity & $\mathrm{CNI}^{\mathrm{d}}$ levels \\
\hline & Drug toxicity, other than $\mathrm{CNI}^{\mathrm{d}}$ & Drug history \\
\hline & Pre-renal cause & Medical history \\
\hline & Delayed recovery from CIT $^{\mathrm{h}}$ & Zero time/pre-implantation biopsy \\
\hline \multirow[t]{4}{*}{ Thrombotic microangiopathy } & $\mathrm{CNI}^{\mathrm{d}}$ toxicity & $\mathrm{CNI}^{\mathrm{d}}$ levels \\
\hline & $\mathrm{AMR}^{\mathrm{e}}$ & Presence of DSA ${ }^{\mathrm{f}}$ \\
\hline & Recurrent disease & Medical history \\
\hline & De novo HUS & Genetic testing \\
\hline \multirow[t]{9}{*}{ Interstitial fibrosis/tubular atrophy } & Chronic/repeated rejection & Previous biopsies \\
\hline & & $\operatorname{DSA}^{\mathrm{f}}$ \\
\hline & Pyelonephritis & Urine culture \\
\hline & Recurrent glomerular disease & Electron microscopy/special stains \\
\hline & De novo glomerular disease & \\
\hline & $\mathrm{CNI}^{\mathrm{d}}$ toxicity & $\mathrm{CNI}^{\mathrm{d}}$ levels/duration \\
\hline & PVAN $^{\mathrm{a}}$ & Special stains ${ }^{\mathrm{b}}$ \\
\hline & & Blood virus PCR \\
\hline & Reno-vascular disease & Medical history \\
\hline
\end{tabular}

However, none of these histological features, which have been described during the first decade of calcineurin inhibitors when higher doses where administered, is specific for calcineurin inhibitor toxicity and can be observed in kidneys from patients who never received calcineurin inhibitors [71]. Thus, the actual contribution of calcineurin inhibitors to renal
Afferent arterioles can display smooth muscle cell necrosis with vacuolization. Uncommonly, thrombotic microangiopathy can develop. Chronic CNI-mediated toxicity leads to deposition of hyaline material in the media of arterioles with a pearl necklace-like appearance. The interstitium may also display striped fibrosis and tubular atrophy. 
allograft loss as well as a reliable risk-benefit analysis of calcineurin inhibitors is still a matter of ongoing debate [72].

Differential diagnosis: interstitial fibrosis/tubular atrophy (IF/TA)

In the past, the term "chronic allograft nephropathy (CAN)" has been widely used in the literature to describe a final common fade of kidney allografts. Unfortunately, this term more and more became a waste basket for a variety of poorly understood conditions in fact representing different disease entities. However, it is obvious that the key to deciphering the reasons for allograft failure is the understanding of individual diseases rather than interpreting CAN as an entity [3, 72]. Therefore, the term CAN has been eliminated from the Banff classification and the use of IF/TA is reserved for those cases only in which no specific disease entity can be identified as the cause of chronic allograft damage after taking into consideration all available clinical, serological, and histological information [73].

\section{Key summary points}

While T-cell-mediated rejection is well controlled with modern immunosuppressive drugs, antibody-mediated rejection is increasingly recognized as a major contributor to renal allograft loss. As it should be the paramount aim to uncover specific diseases in kidney allograft biopsies, the use of the unspecific term "chronic allograft nephropathy" is discouraged.

\section{Key research points}

The histopathological diagnostic criteria for antibodymediated kidney allograft rejection are currently under review, as the morphological spectrum of this disease is expanding. The utility of complement split product $\mathrm{C} 4 \mathrm{~d}$ is limited because of its lack of sensitivity. "C4d-negative antibody-mediated rejection" is now widely recognized.

\section{Questions (answers are provided following the reference list)}

1. Antibody-mediated (humoral) rejection-What is correct?

a. Is exceedingly rare later than 1 year after transplantation

b. Presents with tubulitis in the kidney biopsy

c. Is one important contributor to allograft loss

d. Only affects ABO-incompatible transplant recipients

2. Chronic antibody-mediated rejection-What is wrong?

a. Is characterized by structural remodeling of the kidney microvasculature b. By definition requires detection of a donor-specific antibody

c. Is synonymous to "chronic allograft nephropathy"

d. Electron microscopy is a helpful diagnostic tool in this context

3. Endarteritis/Endothelialitis - What is wrong?

a. Is considered a sign of T-cell-mediated rejection according to the current Banff classification

b. Is currently disregarded for the diagnosis of acute rejection if not accompanied by an interstitial inflammatory infiltrate or tubulitis

c. May be antibody mediated in some cases

d. Affects small as well as larger intrarenal arteries

4. ABO-incompatible transplantation-What is wrong?

a. Diagnosis of antibody-mediated rejection in these cases is based upon presence or absence of $\mathrm{C} 4 \mathrm{~d}$ staining in peritubular capillaries

b. The outcome is comparable to ABO-compatible kidney transplantation

c. Is performed in children as well as in adults

d. May represent one of the scenarios in which accommodation occurs.

5. Borderline acute cellular rejection-What is correct?

a. Designates cases in which a diagnosis of acute cellular rejection can not be made because of insufficient material

b. Designates cases that are "borderline" between acute cellular and acute humoral rejection

c. Designates cases in which either the amount of interstitial infiltrate or the degree of tubulitis is not sufficient to make a diagnosis of acute cellular rejection

d. Is always treated as an acute cellular rejection

\section{References}

1. North American Pediatric Renal Trials and Collaborative Studies (NAPRTCS) 2010 Annual Report available online at https://web. emmes.com/study/ped/annlrept/annlrept.html (31/08/13)

2. ERA-EDTA Registry Annual Report 2010 available online at http:// www.era-edta-reg.org/index.jsp? $\mathrm{p}=14(31 / 08 / 13)$

3. Sellarés J, De Freitas DG, Mengel M, Reeve J, Einecke G, Sis B, Hidalgo LG, Famulski K, Matas A, Halloran PF (2012) Understanding the causes of kidney transplant failure: the dominant role of antibodymediated rejection and nonadherence. Am J Transplant 12:388-399

4. Dobbels F, Van Damme-Lombaert R, Vanhaecke J, De Geest S (2005) Growing pains: non-adherence with the immunosuppressive regimen in adolescent transplant recipients. Pediatr Transplant 9: 381-390

5. Cochat P, Fargue S, Mestrallet G, Jungraithmayr T, Koch-Nogueira $P$, Ranchin B, Zimmerhackl LB (2009) Disease recurrence in paediatric renal transplantation. Pediatr Nephrol 24:2097-2108

6. Ettenger RB, Blifeld C, Prince H, Gradus DB, Cho S, Sekiya N, Salusky IB, Fine RN (1987) The pediatric nephrologist's dilemma: 
growth after renal transplantation and its interaction with age as a possible immunologic variable. J Pediatr 111:1022-1025

7. Scornik JC, Pfaff WW, Howard RJ, Fennell RS 3rd, Ramos E, Peterson JC, Neiberger R (1994) Increased antibody responsiveness to blood transfusions in pediatric patients. Transplantation 58:1361-1365

8. Matas AJ, Smith JM, Skeans MA, Lamb KE, Gustafson SK, Samana CJ, Stewart DE, Snyder JJ, Israni AK, Kasiske BL (2013) OPTN/ SRTR 2011 Annual Data Report: kidney. Am J Transplant 13:11-46

9. Furness PN, Philpott CM, Chorbadjian MT, Nicholson ML, Bosmans J-L, Corthouts BL, Bogers JJPM, Schwarz A, Gwinner W, Haller H, Mengel M, Seron D, Moreso F, Cañas C (2003) Protocol biopsy of the stable renal transplant: a multicenter study of methods and complication rates. Transplantation 76:969-973

10. Mengel M, Chapman JR, Cosio FG, Cavaillé-Coll MW, Haller H, Halloran PF, Kirk AD, Mihatsch MJ, Nankivell BJ, Racusen LC, Roberts IS, Rush DN, Schwarz A, Serón D, Stegall MD, Colvin RB (2007) Protocol biopsies in renal transplantation: insights into patient management and pathogenesis. Am J Transplant 7:512-517

11. Mengel M, Sis B, Haas M, Colvin RB, Halloran PF, Racusen LC, Solez K, Cendales L, Demetris AJ, Drachenberg CB, Farver CF, Rodriguez ER, Wallace WD, Glotz D (2012) Banff 2011 Meeting report: new concepts in antibody-mediated rejection. Am J Transplant 12:563-570

12. Nankivell BJ, Borrows RJ, Fung CL-S, O'Connell PJ, Allen RDM, Chapman JR (2003) The natural history of chronic allograft nephropathy. N Engl J Med 349:2326-2333

13. Kanzelmeyer NK, Ahlenstiel T, Drube J, Froede K, Kreuzer M, Broecker V, Ehrich JHH, Melk A, Pape L (2010) Protocol biopsydriven interventions after pediatric renal transplantation. Pediatr Transplant 14:1012-1018

14. Birk PE (2012) Surveillance biopsies in children post-kidney transplant. Pediatr Nephrol 27:753-760

15. Tait BD, Süsal C, Gebel HM, Nickerson PW, Zachary AA, Claas FHJ, Reed EF, Bray RA, Campbell P, Chapman JR, Coates PT, Colvin RB, Cozzi E, Doxiadis IIN, Fuggle SV, Gill J, Glotz D, Lachmann N, Mohanakumar T, Suciu-Foca N, SumitranHolgersson S, Tanabe K, Taylor CJ, Tyan DB, Webster A, Zeevi A, Opelz G (2013) Consensus guidelines on the testing and clinical management issues associated with HLA and non-HLA antibodies in transplantation. Transplantation 95:19-47

16. Halloran PF (2004) Immunosuppressive drugs for kidney transplantation. N Engl J Med 351:2715-2729

17. Emovon OE, King JAC, Smith SR, Op't Holt C, McDonald F, Howell DN, Browne BJ (2003) Clinical significance of eosinophils in suspicious or borderline renal allograft biopsies. Clin Nephrol 59: 367-372

18. Einecke G, Broderick G, Sis B, Halloran PF (2007) Early loss of renal transcripts in kidney allografts: relationship to the development of histologic lesions and alloimmune effector mechanisms. Am J Transplant 7:1121-1130

19. Minervini MI, Torbenson M, Scantlebury V, Vivas C, Jordan M, Shapiro R, Randhawa PS (2000) Acute renal allograft rejection with severe tubulitis (Banff 1997 grade IB). Am J Surg Pathol 24:553-558

20. Sis B, Mengel M, Haas M, Colvin RB, Halloran PF, Racusen LC, Solez K, Baldwin WM, Bracamonte ER, Broecker V, Cosio F, Demetris AJ, Drachenberg C, Einecke G, Gloor J, Glotz D, Kraus E, Legendre C, Liapis H, Mannon RB, Nankivell BJ, Nickeleit V, Papadimitriou JC, Randhawa P, Regele H, Renaudin K, Rodriguez ER, Seron D, Seshan S, Suthanthiran M, Wasowska BA, Zachary A, Zeevi A (2010) Banff'09 meeting report: antibody-mediated graft deterioration and implementation of Banff working groups. Am J Transplant 10:464-471

21. De Freitas DG, Sellarés J, Mengel M, Chang J, Hidalgo LG, Famulski KS, Sis B, Einecke G, Halloran PF (2012) The nature of biopsies with "borderline rejection" and prospects for eliminating this category. Am J Transplant 12:191-201
22. Meehan SM, Siegel CT, Aronson AJ, Bartosh SM, Thistlethwaite JR, Woodle ES, Haas M (1999) The relationship of untreated borderline infiltrates by the Banff criteria to acute rejection in renal allograft biopsies. J Am Soc Nephrol 10:1806-1814

23. Colvin RB, Cohen AH, Saiontz C, Bonsib S, Buick M, Burke B, Carter S, Cavallo T, Haas M, Lindblad A, Manivel JC, Nast CC, Salomon D, Weaver C, Weiss M (1997) Evaluation of pathologic criteria for acute renal allograft rejection: reproducibility, sensitivity, and clinical correlation. J Am Soc Nephrol 8:1930-1941

24. Racusen LC, Colvin RB, Solez K, Mihatsch MJ, Halloran PF, Campbell PM, Cecka MJ, Cosyns J-P, Demetris AJ, Fishbein MC, Fogo A, Furness P, Gibson IW, Glotz D, Hayry P, Hunsickern L, Kashgarian M, Kerman R, Magil AJ, Montgomery R, Morozumi K, Nickeleit V, Randhawa P, Regele H, Seron D, Seshan S, Sund S, Trpkov K (2003) Antibody-mediated rejection criteria - an addition to the Banff 97 classification of renal allograft rejection. Am J Transplant 3:708-714

25. Hancock WW, Thomson NM, Atkins RC (1983) Composition of interstitial cellular infiltrate identified by monoclonal antibodies in renal biopsies of rejecting human renal allografts. Transplantation 35: 458-463

26. Sarwal M, Chua M-S, Kambham N, Hsieh S-C, Satterwhite T, Masek M, Salvatierra O Jr (2003) Molecular heterogeneity in acute renal allograft rejection identified by DNA microarray profiling. N Engl J Med 349:125-138

27. Hippen BE, DeMattos A, Cook WJ, Kew CE 2nd, Gaston RS (2005) Association of CD20+ infiltrates with poorer clinical outcomes in acute cellular rejection of renal allografts. Am J Transplant 5:2248-2252

28. Charney DA, Nadasdy T, Lo AW, Racusen LC (1999) Plasma cellrich acute renal allograft rejection. Transplantation 68:791-797

29. Gärtner V, Eigentler TK, Viebahn R (2006) Plasma cell-rich rejection processes in renal transplantation: morphology and prognostic relevance. Transplantation 81:986-991

30. Eikmans M, Roos-van Groningen MC, Sijpkens YWJ, Ehrchen J, Roth J, Baelde HJ, Bajema IM, De Fijter JW, De Heer E, Bruijn JA (2005) Expression of surfactant protein-C, S100A8, S100A9, and B cell markers in renal allografts: investigation of the prognostic value. J Am Soc Nephrol 16:3771-3786

31. Kayler LK, Lakkis FG, Morgan C, Basu A, Blisard D, Tan HP, McCauley J, Wu C, Shapiro R, Randhawa PS (2007) Acute cellular rejection with CD20-positive lymphoid clusters in kidney transplant patients following lymphocyte depletion. Am J Transplant 7:949-954

32. Bagnasco SM, Tsai W, Rahman MH, Kraus ES, Barisoni L, Vega R, Racusen LC, Haas M, Mohammed BS, Zachary AA, Montgomery RA (2007) CD20-positive infiltrates in renal allograft biopsies with acute cellular rejection are not associated with worse graft survival. Am J Transplant 7:1968-1973

33. Reff ME, Carner K, Chambers KS, Chinn PC, Leonard JE, Raab R, Newman RA, Hanna N, Anderson DR (1994) Depletion of B cells in vivo by a chimeric mouse human monoclonal antibody to CD20. Blood 83:435-445

34. Mengel M, Gwinner W, Schwarz A, Bajeski R, Franz I, Bröcker V, Becker T, Neipp M, Klempnauer J, Haller H, Kreipe H (2007) Infiltrates in protocol biopsies from renal allografts. Am J Transplant 7:356-365

35. Moreso F, Seron D, O'Valle F, Ibernon M, Gomà M, Hueso M, Cruzado JM, Bestard O, Duarte V, Del Moral RG, Grinyó JM (2007) Immunephenotype of glomerular and interstitial infiltrating cells in protocol renal allograft biopsies and histological diagnosis. Am J Transplant 7:2739-2747

36. Thaunat O, Patey N, Morelon E, Michel J-B, Nicoletti A (2006) Lymphoid neogenesis in chronic rejection: the murderer is in the house. Curr Opin Immunol 18:576-579

37. Ding Q, Yeung M, Camirand G, Zeng Q, Akiba H, Yagita H, Chalasani G, Sayegh MH, Najafian N, Rothstein DM (2011) Regulatory B cells are identified by expression of TIM-1 and can 
be induced through TIM-1 ligation to promote tolerance in mice. $\mathrm{J}$ Clin Invest 121:3645-3656

38. Haas M, Kraus ES, Samaniego-Picota M, Racusen LC, Ni W, Eustace JA (2002) Acute renal allograft rejection with intimal arteritis: histologic predictors of response to therapy and graft survival. Kidney Int 61:1516-1526

39. Nickeleit V, Vamvakas EC, Pascual M, Poletti BJ, Colvin RB (1998) The prognostic significance of specific arterial lesions in acute renal allograft rejection. J Am Soc Nephrol 9:1301-1308

40. Lefaucheur C, Loupy A, Vernerey D, Duong-Van-Huyen J-P, Suberbielle C, Anglicheau D, Vérine J, Beuscart T, Nochy D, Bruneval P, Charron D, Delahousse M, Empana J-P, Hill GS, Glotz D, Legendre C, Jouven X (2013) Antibody-mediated vascular rejection of kidney allografts: a population-based study. Lancet 381:313-319

41. Hill GS, Nochy D, Bruneval P, van Huyen JPD, Glotz D, Suberbielle C, Zuber J, Anglicheau D, Empana J-P, Legendre C, Loupy A (2011) Donor-specific antibodies accelerate arteriosclerosis after kidney transplantation. J Am Soc Nephrol 22:975-983

42. Sellarés J, De Freitas DG, Mengel M, Sis B, Hidalgo LG, Matas AJ, Kaplan B, Halloran PF (2011) Inflammation lesions in kidney transplant biopsies: association with survival is due to the underlying diseases. Am J Transplant 11:489-499

43. Mannon RB, Matas AJ, Grande J, Leduc R, Connett J, Kasiske B, Cecka JM, Gaston RS, Cosio F, Gourishankar S, Halloran PF, Hunsicker L, Rush D (2010) Inflammation in areas of tubular atrophy in kidney allograft biopsies: a potent predictor of allograft failure. Am J Transplant 10:2066-2073

44. Moreso F, Ibernon M, Gomà M, Carrera M, Fulladosa X, Hueso M, GilVernet S, Cruzado JM, Torras J, Grinyó JM, Serón D (2006) Subclinical rejection associated with chronic allograft nephropathy in protocol biopsies as a risk factor for late graft loss. Am J Transplant 6:747-752

45. Shishido S, Asanuma H, Nakai H, Mori Y, Satoh H, Kamimaki I, Hataya H, Ikeda M, Honda M, Hasegawa A (2003) The impact of repeated subclinical acute rejection on the progression of chronic allograft nephropathy. J Am Soc Nephrol 14:1046-1052

46. Solez K, Colvin RB, Racusen LC, Haas M, Sis B, Mengel M, Halloran PF, Baldwin W, Banfi G, Collins AB, Cosio F, David DSR, Drachenberg C, Einecke G, Fogo AB, Gibson IW, Glotz D, Iskandar SS, Kraus E, Lerut E, Mannon RB, Mihatsch M, Nankivell BJ, Nickeleit V, Papadimitriou JC, Randhawa P, Regele H, Renaudin K, Roberts I, Seron D, Smith RN, Valente M (2008) Banff 07 classification of renal allograft pathology: updates and future directions. Am J Transplant 8:753-760

47. Mengel M, Reeve J, Bunnag S, Einecke G, Jhangri GS, Sis B, Famulski K, Guembes-Hidalgo L, Halloran PF (2009) Scoring total inflammation is superior to the current Banff inflammation score in predicting outcome and the degree of molecular disturbance in renal allografts. Am J Transplant 9:1859-1867

48. Einecke G, Sis B, Reeve J, Mengel M, Campbell PM, Hidalgo LG, Kaplan B, Halloran PF (2009) Antibody-mediated microcirculation injury is the major cause of late kidney transplant failure. Am J Transplant 9:2520-2531

49. Gaston RS, Cecka JM, Kasiske BL, Fieberg AM, Leduc R, Cosio FC, Gourishankar S, Grande J, Halloran P, Hunsicker L, Mannon R, Rush D, Matas AJ (2010) Evidence for antibody-mediated injury as a major determinant of late kidney allograft failure. Transplantation 90:68-74

50. Kissmeyer-Nielsen F, Olsen S, Petersen VP, Fjeldborg O (1966) Hyperacute rejection of kidney allografts, associated with preexisting humoral antibodies against donor cells. Lancet 2:662-665

51. Ahern AT, Artruc SB, DellaPelle P, Cosimi AB, Russell PS, Colvin RB, Fuller TC (1982) Hyperacute rejection of HLA-AB-identical renal allografts associated with B lymphocyte and endothelial reactive antibodies. Transplantation 33:103-106

52. Colvin RB, Smith RN (2005) Antibody-mediated organ-allograft rejection. Nat Rev Immunol 5:807-817
53. Cornell LD, Smith RN, Colvin RB (2008) Kidney transplantation: mechanisms of rejection and acceptance. Annu Rev Pathol 3:189220

54. Akiyoshi T, Hirohashi T, Alessandrini A, Chase CM, Farkash EA, Neal Smith R, Madsen JC, Russell PS, Colvin RB (2012) Role of complement and NK cells in antibody-mediated rejection. Hum Immunol 73:1226-1232

55. Lipták P, Kemény E, Morvay Z, Szederkényi E, Szenohradszky P, Marofka F, Toldi J, Exner M, Iványi B (2005) Peritubular capillary damage in acute humoral rejection: an ultrastructural study on human renal allografts. Am J Transplant 5:2870-2876

56. Wavamunno MD, O'Connell PJ, Vitalone M, Fung CL-S, Allen RDM, Chapman JR, Nankivell BJ (2007) Transplant glomerulopathy: ultrastructural abnormalities occur early in longitudinal analysis of protocol biopsies. Am J Transplant 7:2757-2768

57. Mengel M, Chan S, Climenhaga J, Kushner YB, Regele H, Colvin RB, Randhawa P (2013) Banff Initiative for Quality Assurance in Transplantation (BIFQUIT): reproducibility of $\mathrm{C} 4 \mathrm{~d}$ immunohistochemistry in kidney allografts. Am J Transplant 13:1235-1245

58. Sis B, Jhangri GS, Bunnag S, Allanach K, Kaplan B, Halloran PF (2009) Endothelial gene expression in kidney transplants with alloantibody indicates antibody-mediated damage despite lack of $\mathrm{C} 4 \mathrm{~d}$ staining. Am J Transplant 9:2312-2323

59. Haas M (2011) C4d-negative antibody-mediated rejection in renal allografts: evidence for its existence and effect on graft survival. Clin Nephrol 75:271-278

60. Takahashi K (2007) Recent findings in ABO-incompatible kidney transplantation: classification and therapeutic strategy for acute antibody-mediated rejection due to ABO-blood-group-related antigens during the critical period preceding the establishment of accommodation. Clin Exp Nephrol 11:128-141

61. Haas M, Rahman MH, Racusen LC, Kraus ES, Bagnasco SM, Segev DL, Simpkins CE, Warren DS, King KE, Zachary AA, Montgomery RA (2006) C4d and C3d staining in biopsies of ABO- and HLAincompatible renal allografts: correlation with histologic findings. Am J Transplant 6:1829-1840

62. Montgomery RA, Cozzi E, West LJ, Warren DS (2011) Humoral immunity and antibody-mediated rejection in solid organ transplantation. Semin Immunol 23:224-234

63. Hirsch HH, Vincenti F, Friman S, Tuncer M, Citterio F, Wiecek A, Scheuermann EH, Klinger M, Russ G, Pescovitz MD, Prestele H (2013) Polyomavirus BK replication in de novo kidney transplant patients receiving tacrolimus or cyclosporine: a prospective, randomized, multicenter study. Am J Transplant 13:136-145

64. Hirsch HH, Brennan DC, Drachenberg CB, Ginevri F, Gordon J, Limaye AP, Mihatsch MJ, Nickeleit V, Ramos E, Randhawa P, Shapiro R, Steiger J, Suthanthiran M, Trofe J (2005) Polyomavirusassociated nephropathy in renal transplantation: interdisciplinary analyses and recommendations. Transplantation 79:1277-1286

65. Schaub S, Hirsch HH, Dickenmann M, Steiger J, Mihatsch MJ, Hopfer H, Mayr M (2010) Reducing immunosuppression preserves allograft function in presumptive and definitive polyomavirusassociated nephropathy. Am J Transplant 10:2615-2623

66. Drachenberg CB, Papadimitriou JC, Hirsch HH, Wali R, Crowder C, Nogueira J, Cangro CB, Mendley S, Mian A, Ramos E (2004) Histological patterns of polyomavirus nephropathy: correlation with graft outcome and viral load. Am J Transplant 4:2082-2092

67. Fishman JA (2007) Infection in solid-organ transplant recipients. N Engl J Med 357:2601-2614

68. Nickeleit V, Mihatsch MJ (2004) Polyomavirus allograft nephropathy and concurrent acute rejection: a diagnostic and therapeutic challenge. Am J Transplant 4:838-839

69. Masutani K, Shapiro R, Basu A, Tan H, Wijkstrom M, Randhawa P (2012) The Banff 2009 working proposal for polyomavirus nephropathy: a critical evaluation of its utility as a determinant of clinical outcome. Am J Transplant 12:907-918 
70. Mihatsch MJ, Thiel G, Ryffel B (1988) Histopathology of cyclosporine nephrotoxicity. Transplant Proc 20:759-771

71. Bröcker V, Schubert V, Scheffner I, Schwarz A, Hiss M, Becker JU, Scherer R, Haller H, Kreipe HH, Mengel M, Gwinner W (2012) Arteriolar lesions in renal transplant biopsies: prevalence, progression, and clinical significance. Am J Pathol 180:1852-1862

72. El-Zoghby ZM, Stegall MD, Lager DJ, Kremers WK, Amer H, Gloor JM, Cosio FG (2009) Identifying specific causes of kidney allograft loss. Am J Transplant 9:527-535

73. Solez K, Colvin RB, Racusen LC, Sis B, Halloran PF, Birk PE, Campbell PM, Cascalho M, Collins AB, Demetris AJ, Drachenberg CB, Gibson IW, Grimm PC, Haas M, Lerut E, Liapis H, Mannon RB, Marcus PB, Mengel M, Mihatsch MJ, Nankivell BJ, Nickeleit V, Papadimitriou JC, Platt JL, Randhawa P, Roberts I, Salinas-Madriga
L, Salomon DR, Seron D, Sheaff M, Weening JJ (2007) Banff “05 Meeting Report: differential diagnosis of chronic allograft injury and elimination of chronic allograft nephropathy ("CAN'). Am J Transplant 7:518-526

\section{Correct answers to questions:}

$1 \mathrm{C}$

$2 \mathrm{C}$

$3 \mathrm{~B}$

$4 \mathrm{~A}$

$5 \mathrm{C}$ 